\title{
Effect of Use of Different Anthelmintics (Piperazine Citrate and Ivermectine) on Blood Profile of Infested Poultry (Commercial and Rural Layers)
}

\author{
Ghulam Abbas ${ }^{1, *}$, Muhammad Zia Ur Rehman ${ }^{2}$, Asghar Ali $^{2}$, Muhammad Fiaz $^{2}$, Ashar Mahfooz $^{3}$ \\ ${ }^{1}$ Department of Poultry Science, University of Agriculture, Pakistan \\ ${ }^{2}$ Livestock and Dairy Development Department, Pakistan \\ ${ }^{3}$ Department of Clinical Medicine and Surgery, University of Agriculture, Pakistan
}

Copyright $\subset 2016$ by authors, all rights reserved. Authors agree that this article remains permanently open access under the terms of the Creative Commons Attribution License 4.0 International License

\begin{abstract}
This research was conducted to describe the therapeutic effect of ivermectin and piperazine citrate on blood profile in commercial layer birds and rural poultry. Two experiments named 1 and 2 were performed representing commercial layer birds and rural poultry respectively. Each experiment was consisted of 4 groups of 15 birds each named A, B, C, D, (Experiment No 1) and W, $\mathrm{X}, \mathrm{Y}$ and $\mathrm{Z}$ (Experiment No 2). To make the birds parasitic free, Albendazole $@ 14 \mathrm{mg} / \mathrm{Kg}$ were administered in all birds. In subgroups A, B, C, W, X and Y Ascaridia galli infection was inoculated orally @ dose rate of 2500 embryonated eggs per bird using crop tube. To confirm infestation 5 birds were euthanized from each treatment group at day $28^{\text {th }}$ of post infection. Ivermectin @ dose rate of $200 \mu \mathrm{g} / \mathrm{kg}$ was given in birds of treatment groups A and W, and Piperazine citrate @ dose rate of $32 \mathrm{mg} / 100 \mathrm{~kg}$ in birds of treatment groups $\mathrm{C}$ and Z. At day $10^{\text {th }}$ (post treatment) six birds from each group were blood sampled to check blood profile. Blood analysis showed same $(\mathrm{P}>0.05)$ effect of both anthelmintics on serum cholesterol, serum T3, serum creatinine, serum cortisol level, ESR and respiratory rate of infested birds whilst Piperazine citrate administration showed higher $(\mathrm{P}<$ $0.05)$ serum T4 level, and lower $(\mathrm{P}<0.05)$ serum urea level in infested birds.
\end{abstract}

Keywords Infestation, Piperazine Citrate, Ivermectin, Blood Profile, Poultry

\section{Introduction}

Parasitic infections are considered a disaster for production performance of poultry especially rural poultry carry high parasitic burden [6] however, it is often neglected. Recently helminthosis is considered one of the most common injurious for poultry all over the world $[15,13]$.
Parasitism may prove fatal to young and weak poultry also fatal to human through transmission of zoonotic diseases [1].

Different anthelmintics drugs have varying broad spectrum activity against nematode worms and ectoparasites in poultry, and have been in use from the last four decades. Ivermectin is moderately well absorbed following oral administration and its dose ranges from 20 to $300 \mu \mathrm{g} / \mathrm{kg}$ body weight [7]. Different biologists have demonstrated relation of ivermectin and worms in different ways. Piperazine is a pharmacological analogue of a natural inhibitory neurohormone and is a drug of choice against helminthes. It has also been studied that the use of herbal growth promoters have positive effect on overall health status of birds and also helpful in controlling the intestinal parasites [11, 12]. However work on the effect of anthelmintics on blood profile and physiology of birds is very scant. Therefore the present project was designed to check the comparative effect of two vastly used prominent anthelmintic (Piperazine vs Piperazine citrate) on physiology and blood profile of poultry birds.

\section{Materials and Methods}

\section{Experimental Protocol}

A total of 120 birds (60 commercial layer white leg horn birds named group 1 and 60 rural poultry birds named group 2 ) were purchased from the farms and villages of about 7 to 9 week age and brought to the poultry shed of Department of Clinical Medicine and Surgery, University of Agriculture, Faisalabad. For 7 days birds were fed (commercial feed ad libitum to acclimatize. After seven days the two groups $(\mathrm{n}=120)$ were dewormed with albendazole @ $14 \mathrm{mg} / \mathrm{kg}$ to make the birds free from any parasitic infestation [5]. Dropping of all birds were collected (after a week) to confirm infestation free [16]. The parasitic free commercial layer birds $(n=60)$ were divided in to 4 groups named A, B, C, 
D (Experiment 1$)$ and the rural poultry birds $(n=60)$ were divided into four subgroups $\mathrm{W}, \mathrm{X}, \mathrm{Y}$ and $\mathrm{Z}$ (Experiment 2). Each group comprised of 15 birds. In groups A, B, C, W, X and Y Ascaridia galli infection was inoculated orally @ dose rate of 2500 embryonated eggs per bird in dilution with buffer solution with crop tube.

EXPERIMENT NO. 1

\begin{tabular}{|c|c|}
\hline SUB GROUP & INFECTION \\
\hline A & Infection + Ivermectin \\
\hline B & Infection+Piperazine citrate \\
\hline C & Infected unmedicated \\
\hline D & Control ( uninfected unmedicated \\
\hline
\end{tabular}

EXPERIMENT NO. 2

\begin{tabular}{|c|c|}
\hline SUB GROUP & INFECTION \\
\hline $\mathrm{W}$ & Infection + Ivermectin \\
\hline $\mathrm{X}$ & Infection+Piperazine citrate \\
\hline $\mathrm{Y}$ & Infected unmedicated \\
\hline $\mathrm{Z}$ & Control (Uninfected unmedicated \\
\hline
\end{tabular}

Ivermectin $\quad=200 \mu \mathrm{g} / \mathrm{Kg}$

Piperazine citrate $=32 \mathrm{mg} / \mathrm{Kg}$

Birds of groups $\mathrm{C}$ and $\mathrm{Y}$ were kept as positive control (infected) and groups D and $\mathrm{Z}$ were kept as absolute control (Uninfected unmedicated). At day $28^{\text {th }}$ (post-infection), droppings were examined by applying direct smear method and centrifuge floatation technique. Then Ivotek ${ }^{\mathrm{R}}$ (Star Labs) (a) $.75 \mathrm{ml}$ was administered each bird of group A and $\mathrm{W}$ and Digestion ${ }^{\mathrm{R}}$ (UT D) @ dose rate of 2.5gm was given to birds of group $B$ and $X$. Then at $38^{\text {th }}$ day post infection $\left(10^{\text {th }}\right.$ day post medication) blood samples were collected (six birds / group). These samples were collected from brachial vein of birds in $5 \mathrm{ml}$ sterilized B. D. syringes. After collection of blood these syringes were kept in slanted position to obtain serum from the samples. The serum was collected in sterilized $0.5 \mathrm{ml}$ serum cups. Serum cortisol level, T3 level, T4 level, creatinine level, cholesterol level, urea level and ESR level were determined as described by [16], [10], [4] and [9].

Statistical Analysis: The data thus collected was subjected to statistical analysis for the interpretation of results using analysis of variance technique with completely randomized design. Treatment means were compared by Duncan Multiple Range test [17].

\section{Results and Discussion}

Piperazine citrate and Ivermectin administration did not show any significant change $(\mathrm{P}>0.05)$ on serum cholesterol level in commercial as well as backyard layers (Table 1). The results are contrary to [2] who noticed a rise in cholesterol level by administration of piperazine citrate in broiler chickens. On the other hand some scientists have observed the decrease in cholesterol level in poultry by ginger and black pepper along with their anthelmintic activity [19]. Serum T3 level was not affected significantly $(\mathrm{P}>0.05)$ due to anthelmintic treatment groups (Table 2) however mean value of serum $\mathrm{T} 3$ hormone was significantly higher $(\mathrm{P}<$ 0.05 ) in commercial layers which might be due to species variation. Administration of anthelmintic whilst treating the infestation caused significant effect $(\mathrm{P}<0.05)$ on $\mathrm{T} 4$ hormone level (Table 3 ) in commercial and rural poultry. Highest T4 level was observed in birds not infected nor medicated whilst that of lowest observed in birds infested with worms but not medicated in both types of layers (commercial and rural). However, piperazine citrate administration showed better level of T4 hormone in infested birds (commercial and rural) as compared to Ivermectin. This might be due to better anthelmintic ability of piperazine citrate against nematodes as compared to ivermectin. The results show that the fluctuation in the value of T4 is much higher in commercial poultry layer as compared to backyard poultry. This might be due to genetic makeup of the commercial poultry that it shows quick response to the environmental and other physical changes. Differences in serum creatinine level among treated and untreated groups were found to be non-significant $(P>0.05)$ (Table 4). Use of anthelmintics (piperazine citrate and ivermectin) showed non-significant effect on serum creatinine level in commercial and rural layers. It was observed that whilst treating infestation by administrating anthelmintics (piperazine and ivermectin), serum urea level affected significantly (Table 5). Highest serum urea level was observed in birds infested but not treated with anthelmintics however birds infested with $A$. galli and afterward treated with piperazine citrate showed lowest serum urea level in commercial layer. This disparity might be due to more response of commercial layer to piperazine citrate in fight against $A$. galli as compared to rural poultry birds. Serum cortisol level in rural and commercial birds was not significantly affected by anthelmintics (Table 6) however cortisol level was significantly more in commercial layers. Possible reason might be natural resistance developed in backyard poultry against worms leading to less stress which resulted less cortisol level.

Comparative therapeutic effect of both anthelmintics (Piperazine and Ivermectin) was not significant (Table 7). This result is contrary to [20] who found better efficacy of piperazine than ivermectin as anthelmintic. However, infection rate (ESR) was significantly higher in birds of group infected but not treated with anthelmintic $(\mathrm{P}>0-05)$. ESR level was high in birds which were infested but not given any anthelmintic therapy in both types of layers (commercial and rural). These findings are compatible to that of [8] and [18] who reported that ESR values decreases in anthelmintics treated groups.

Respiratory rate was significantly higher in birds of group $\mathrm{C}$ (commercial layers infected but not treated) and group Y (rural layers infected but not treated). This may be due to the worm burden which causes increase in respiratory rate. 
However, comparative therapeutic effect of piperazine citrate and ivermectin on respiratory rate of birds was not differed significantly which revealed that both drugs have similar positive effect on respiration rate of birds during infestation (Table 8).

[3] Reported that pathological catabolic processes that have been contributed due to the effect of $A$. galli infestation on the middle part of small intestine may cause disturbance of blood profile of birds due to disruption in absorption of nutrients. However administration of the piperazine in the birds caused removal of $A$. galli ultimately restored the capacity of the small intestinal.
The present findings indicates that treatment with both drugs (Piperazine citrate and Ivermectin) have comparable results in terms of haemato-biochemical profile though the treatment however, especially piperazine citrate resulted in remarkable improvement on blood profile of infested commercial layer birds without any side effect. This result also illustrates that the blood profile changes occur in short time after infection in commercial poultry as compared to backyard poultry and simultaneously the positive effect of drug in restoring the blood profile parameters occur earlier in the commercial layer as compared with the backyard poultry.

Table 1. Effect of Piperazine citrate and Ivermectin on plasma cholesterol level in infested commercial and rural layers

\begin{tabular}{|c|c|c|c|c|c|c|c|c|c|}
\hline \multirow{3}{*}{$\begin{array}{c}\text { Group } \\
1\end{array}$} & \multicolumn{6}{|c|}{ Layer } & & \multirow{2}{*}{\multicolumn{2}{|c|}{ Mean }} \\
\hline & \multicolumn{3}{|c|}{ Commercial } & \multicolumn{3}{|c|}{ Desi } & & & \\
\hline & 138.33 & \pm & 0.33 & 139.33 & \pm & 1.33 & 138.83 & \pm & $0.65 \mathrm{~A}$ \\
\hline 2 & 138.00 & \pm & 0.00 & 142.00 & \pm & 3.06 & 140.00 & \pm & $1.63 \mathrm{~A}$ \\
\hline 3 & 138.33 & \pm & 0.33 & 137.67 & \pm & 0.88 & 138.00 & \pm & $0.45 \mathrm{~A}$ \\
\hline 4 & 137.00 & \pm & 1.00 & 137.33 & \pm & 4.06 & 137.17 & \pm & $1.87 \mathrm{~A}$ \\
\hline Mean & 137.92 & \pm & $0.29 \mathrm{~A}$ & 139.08 & \pm & $1.26 \mathrm{~A}$ & & & \\
\hline
\end{tabular}

Means sharing similar letter in a row or in a column are statistically non-significant $(\mathrm{P}>0.05)$.

Table 2. Effect of Piperazine citrate and Ivermectin on plasma T3 Hormone level in infested commercial and rural layers

\begin{tabular}{|c|c|c|c|c|c|c|c|c|c|}
\hline \multirow{3}{*}{$\begin{array}{c}\text { Group } \\
1 \\
\end{array}$} & \multicolumn{6}{|c|}{ Layer } & & \multirow{2}{*}{\multicolumn{2}{|c|}{ Mean }} \\
\hline & \multicolumn{3}{|c|}{ Commercial } & \multicolumn{3}{|c|}{ Desi } & & & \\
\hline & 2.50 & \pm & 0.15 & 2.40 & \pm & 0.12 & 2.45 & \pm & $0.09 \mathrm{~A}$ \\
\hline 2 & 2.60 & \pm & 0.25 & 2.47 & \pm & 0.13 & 2.54 & \pm & $0.13 \mathrm{~A}$ \\
\hline 3 & 2.40 & \pm & 0.06 & 2.20 & \pm & 0.10 & 2.30 & \pm & $0.07 \mathrm{~A}$ \\
\hline 4 & 2.63 & \pm & 0.03 & 2.27 & \pm & 0.09 & 2.45 & \pm & $0.09 \mathrm{~A}$ \\
\hline Mean & 2.53 & \pm & $0.07 \mathrm{~A}$ & 2.33 & \pm & $0.06 \mathrm{~B}$ & & & \\
\hline
\end{tabular}

Means sharing similar letter in a row or in a column are statistically non-significant $(\mathrm{P}>0.05)$.

Table 3. Effect of Piperazine citrate and Ivermectin on plasma T4 Hormone level in infested commercial and rural layers

\begin{tabular}{|c|c|c|c|c|c|c|c|c|c|}
\hline \multirow{3}{*}{$\begin{array}{c}\text { Group } \\
1 \\
\end{array}$} & \multicolumn{6}{|c|}{ Layer } & & \multirow{2}{*}{\multicolumn{2}{|c|}{ Mean }} \\
\hline & \multicolumn{3}{|c|}{ Commercial } & \multicolumn{3}{|c|}{ Desi } & & & \\
\hline & 3.53 & \pm & $0.20 \mathrm{bc}$ & 3.17 & \pm & $0.03 \mathrm{~cd}$ & 3.35 & \pm & $0.12 \mathrm{BC}$ \\
\hline 2 & 3.77 & \pm & $0.15 \mathrm{ab}$ & 3.20 & \pm & $0.12 \mathrm{~cd}$ & 3.48 & \pm & $0.15 \mathrm{AB}$ \\
\hline 3 & 3.13 & \pm & $0.07 \mathrm{~d}$ & 3.10 & \pm & $0.06 \mathrm{~d}$ & 3.12 & \pm & $0.04 \mathrm{C}$ \\
\hline 4 & 4.10 & \pm & $0.15 \mathrm{a}$ & 3.27 & \pm & $0.18 \mathrm{~cd}$ & 3.68 & \pm & $0.21 \mathrm{~A}$ \\
\hline Mean & 3.63 & \pm & $0.12 \mathrm{~A}$ & 3.18 & \pm & $0.05 \mathrm{~B}$ & & & \\
\hline
\end{tabular}

Means sharing similar letter in a row or in a column are statistically non-significant $(\mathrm{P}>0.05)$. Small letters represent comparison among interaction means and capital letters are used for overall mean.

Table 4. Analysis of variance table for Creatinine

\begin{tabular}{|c|c|c|c|c|c|c|c|c|c|}
\hline \multirow{3}{*}{$\begin{array}{c}\text { Group } \\
1\end{array}$} & \multicolumn{6}{|c|}{ Layer } & \multirow{2}{*}{\multicolumn{3}{|c|}{ Mean }} \\
\hline & \multicolumn{3}{|c|}{ Commercial } & \multicolumn{3}{|c|}{ Desi } & & & \\
\hline & 0.69 & \pm & 0.04 & 0.72 & \pm & 0.03 & 0.71 & \pm & $0.02 \mathrm{AB}$ \\
\hline 2 & 0.69 & \pm & 0.02 & 0.65 & \pm & 0.02 & 0.67 & \pm & $0.01 \mathrm{~B}$ \\
\hline 3 & 0.75 & \pm & 0.04 & 0.78 & \pm & 0.06 & 0.77 & \pm & $0.03 \mathrm{~A}$ \\
\hline 4 & 0.69 & \pm & 0.02 & 0.62 & \pm & 0.01 & 0.66 & \pm & $0.02 \mathrm{~B}$ \\
\hline Mean & 0.71 & \pm & $0.02 \mathrm{~A}$ & 0.69 & \pm & $0.02 \mathrm{~A}$ & & & \\
\hline
\end{tabular}

Means sharing similar letter in a row or in a column are statistically non-significant $(\mathrm{P}>0.05)$. 
Table 5. Analysis of variance table for Urea

\begin{tabular}{|c|c|c|c|c|c|c|c|c|c|}
\hline \multirow{2}{*}{ Group } & \multicolumn{7}{|c|}{ Layer } & \multicolumn{3}{c|}{ Mean } \\
\cline { 2 - 11 } & \multicolumn{7}{|c|}{ Commercial } & \multicolumn{3}{c|}{ Desi } & \\
\hline 1 & 42.00 & \pm & $1.15 \mathrm{bc}$ & 40.00 & \pm & $0.58 \mathrm{bc}$ & 41.00 & \pm & $0.73 \mathrm{~B}$ \\
\hline 2 & 39.33 & \pm & $0.67 \mathrm{c}$ & 40.00 & \pm & $1.15 \mathrm{bc}$ & 39.67 & \pm & $0.61 \mathrm{~B}$ \\
\hline 3 & 51.00 & \pm & $2.08 \mathrm{a}$ & 41.00 & \pm & $2.08 \mathrm{bc}$ & 46.00 & \pm & $2.59 \mathrm{~A}$ \\
\hline 4 & 43.33 & \pm & $0.67 \mathrm{~b}$ & 41.33 & \pm & $1.20 \mathrm{bc}$ & 42.33 & \pm & $0.76 \mathrm{~B}$ \\
\hline Mean & 43.92 & \pm & $1.42 \mathrm{~A}$ & 40.58 & \pm & $0.61 \mathrm{~B}$ & & & \\
\hline
\end{tabular}

Means sharing similar letter in a row or in a column are statistically non-significant $(\mathrm{P}>0.05)$. Small letters represent comparison among interaction means and capital letters are used for overall mean.

Table 6. Analysis of variance table for Cortisol

\begin{tabular}{|c|c|c|c|c|c|c|c|c|c|}
\hline \multirow{2}{*}{ Group } & \multicolumn{7}{|c|}{ Layer } & \multicolumn{4}{c|}{ Mean } \\
\cline { 2 - 11 } & \multicolumn{7}{|c|}{ Commercial } & \multicolumn{3}{|c|}{ Desi } \\
\hline 1 & 8.03 & \pm & 0.74 & 7.70 & \pm & 0.44 & 7.87 & \pm & $0.39 \mathrm{~B}$ \\
\hline 2 & 8.67 & \pm & 0.37 & 7.00 & \pm & 0.40 & 7.83 & \pm & $0.45 \mathrm{~B}$ \\
\hline 3 & 9.23 & \pm & 0.22 & 8.57 & \pm & 0.23 & 8.90 & \pm & $0.21 \mathrm{~A}$ \\
\hline 4 & 7.87 & \pm & 0.24 & 7.87 & \pm & 0.35 & 7.87 & \pm & $0.19 \mathrm{~B}$ \\
\hline Mean & 8.45 & \pm & $0.25 \mathrm{~A}$ & 7.78 & \pm & $0.23 \mathrm{~B}$ & & & \\
\hline
\end{tabular}

Means sharing similar letter in a row or in a column are statistically non-significant $(\mathrm{P}>0.05)$.

Table 7. Analysis of variance table for ESR

\begin{tabular}{|c|c|c|c|c|c|c|c|c|c|}
\hline \multirow{2}{*}{ Group } & \multicolumn{7}{|c|}{ Layer } & \multicolumn{4}{c|}{ Mean } \\
\cline { 2 - 11 } & \multicolumn{7}{|c|}{ Commercial } & \multicolumn{3}{|c|}{ Desi } \\
\hline 1 & 3.43 & \pm & 0.09 & 3.63 & \pm & 0.09 & 3.53 & \pm & $0.07 \mathrm{~B}$ \\
\hline 2 & 3.63 & \pm & 0.09 & 3.37 & \pm & 0.12 & 3.50 & \pm & $0.09 \mathrm{~B}$ \\
\hline 3 & 4.83 & \pm & 0.56 & 4.03 & \pm & 0.09 & 4.43 & \pm & $0.31 \mathrm{~A}$ \\
\hline 4 & 3.53 & \pm & 0.18 & 3.50 & \pm & 0.15 & 3.52 & \pm & $0.10 \mathrm{~B}$ \\
\hline Mean & 3.86 & \pm & $0.21 \mathrm{~A}$ & 3.63 & \pm & $0.09 \mathrm{~A}$ & & & \\
\hline
\end{tabular}

Means sharing similar letter in a row or in a column are statistically non-significant $(\mathrm{P}>0.05)$.

Table 8. Analysis of variance table for Respiratory rate

\begin{tabular}{|c|c|c|c|c|c|c|c|c|c|}
\hline \multirow{2}{*}{ Group } & \multicolumn{7}{|c|}{ Layer } & \multicolumn{4}{c|}{ Mean } \\
\cline { 2 - 11 } & \multicolumn{5}{|c|}{ Commercial } & \multicolumn{3}{c|}{ Desi } \\
\hline 1 & 69.67 & \pm & 0.33 & 70.67 & \pm & 0.33 & 70.17 & \pm & $0.31 \mathrm{~B}$ \\
\hline 2 & 70.33 & \pm & 0.33 & 70.00 & \pm & 1.15 & 70.17 & \pm & $0.54 \mathrm{~B}$ \\
\hline 3 & 73.33 & \pm & 0.67 & 72.67 & \pm & 0.67 & 73.00 & \pm & $0.45 \mathrm{~A}$ \\
\hline 4 & 70.33 & \pm & 0.33 & 70.33 & \pm & 0.33 & 70.33 & \pm & $0.21 \mathrm{~B}$ \\
\hline Mean & 70.92 & \pm & $0.47 \mathrm{~A}$ & 70.92 & \pm & $0.43 \mathrm{~A}$ & & & \\
\hline
\end{tabular}

Means sharing similar letter in a row or in a column are statistically non-significant $(\mathrm{P}>0.05)$. 


\section{Conclusions}

Helminthes are very important which have negative impact on poultry health. Different herbal and synthetic elements have been used for control of these helminthes. All the physiological, hematological and hormonal changes which occur as the result of helminthosis are more prominent in commercial poultry than the backyard poultry. However, birds treated with Piperazine citrate showed beneficial effect o physiological, hematological and hormonal profile as compared to those treated with ivermectin. On the basis of the results of the present study it is concluded that Piperazine is comparatively a better drug than ivermectin to control worm infestation.

\section{REFERENCES}

[1] Ahmad B, Ashraf M, Naeem M, Zafar A and Javed M, 2011. Effect of broiler droppings on Indian major carps Growth performance and nitrogen incorporation. J Anim. Pl. Sci., 21: $575-580$.

[2] Ali MA, LI Devi, WM Lyngdoh, G Das, H Parsad, KV Chanu, M Parva, TC Tolenkhomba, YD Singh and MC Lallinchhunga, 2011. Comparative Biochemical Profile of Ascaridia galli Infected Broiler Chickens on Administration of Pineapple and Neem Leaves and Piperazine. Intl J P Sci, 10(7): 542-546.

[3] Anwar, H. and Rahman Zia-ur, 2002. Effect of Ascaridia galli infestation on electrolytes and vitamins in chickens. J. Biol. Sci., 2: 650-651.

[4] Benjamin MM, 1978. Outline of Veterinary Clinical Pathology. 3rd ed. The Iowa State University Press. Ames, Iowa, USA

[5] Chaddha D, Agnihotri R K and Rajesh K, 2005. Efficacy of Albendazole and Levamisole at different dose levels against Ascaridia galli. J Vet Parasitol, 19: 35-37.

[6] Ekpo UF, Ogbooye AA, Oluwole AS, Takeet M, 2010. A preliminary survey on the parasites of free range chicken in Abeokuta, Ogun State, Nigeria. An Inter J Agri Sci Env and Tech, 9: 2 .

[7] Hayes WJ and Laws ER (1991). Handbook of pesticide toxicology. Academic Press, New York, p612-613.

[8] Islam SA, Rahman MM, Hossain MA, Chowdhury MGA and Mostofa M (2005). Comparative efficacy of some modern anthelmintics and Pineapple leaves with their effects on certain blood parameters and body weight gain in calves infected with Ascarid parasites. Bangladesh Journal of Veterinary Medicine 3 (1): 33-37.
[9] Kassirer J, 1971. Clinical evaluation of kidney function-glomerular function. N. Engl. J. Med., p. 385.

[10] Liebermann C, 1985. Determination of cholesterol in blood serum. Chem Ber, 18:1803.

[11] Mahmood S, MF Saleem, F Ahmad, G Abbas, A Mahmood, SH Qamar and Muhammad Zia ur Rehman, 2014. Comparative Effect of Different Commercial Herbal Growth Promoters' on Performance, Minor Body Parts, Weight and Immune Response in Broiler. Advances in Zoology and Botany, 3(4):69-74.

[12] Mahmood S, A Rehman, M Yousaf, P Akhtar and G Abbas, K Hayat, a Mahmood and MK Shahzad, 2015. Comparative Efficacy of Different Herbal Plants' Leaf Extract on Haematology, Intestinal Histomorphology and Nutrient Digestibility in Broilers. Advances in Zoology and Botany, $3(2): 11-16$.

[13] Mwale M and Patrick JM, 2011. Point prevalence study of gastro-intestinal parasites in village chickens of Centane district, South Africa. Afri J Agric Res, 6(9): 2033-2038.

[14] Oelkers, EH, PA Bjorkum, and WM Murphy, 1992. The mechanism of porosity reduction, stylolite development and quartz cementation in North Sea sandstones, in YK Kharaka and AS Maest, eds., Water-rock interaction: Rotterdam, Balkema, v. 2, p. 1183-1186.

[15] Qamar SH, Ahsan ul Haq, N Asghar, Shahid ur Rehman, P Akhtar and G Abbas, 2015. Effect of Herbal Medicine Supplementations (Arsilvon Super, Bedgen 40 and Hepa-cure Herbal Medicines) on Growth Performance, Immunity and Hematological Profile in Broiler. Advances in Zoology and Botany, 3(2):17-23.

[16] Soulsby, E.J.L. (2005) Cestodes. In: Helminths, arthropods and protozoa of domesticated animals, 7th ed, Bailliere Tindall, Elsevier, India.

[17] Steel RGD, JH Torrie and DA Dickey, 1996. Principle and Procedure of Statistics. A biometric approach (3rd.Ed). McGraw Hill Book Comp. Inc. New York, USA, pp: 666.

[18] Sufian AMA, Mostofa M, Choudhury ME, Awal MA and Sarker BC (2006). Comparative efficacy of Alnendazole, Ivermectin and korolla (Momordica charantica) fruit extract against naturally infected ascariasis in indigenous chicken. Progress Agriculture 17 (1): 121-126.

[19] Valiollahi MR, Y Rahimian, Y Miri, F Asgarian and A Rafiee, 2014. Effect of ginger (Zingiber officinale) and black pepper (Piper nigrum L.) powder on performance, haematological parameters and antibody titre in broiler chicks. Res. Opin. Anim. Vet. Sci., 4(3), 128-132.

[20] Rehman Z. U., A Mahfooz, T. Ahmad, S. Mahmood, G. Abbas, M. I. Saleem, A Iqbal, F Siddique, and M. Fiaz. 2014. Comparative therapeutic efficacy of Ivermectin and Piperazine citrate against Ascaridia galli in commercial and rural poultry. Sch Adv Anim Vet Res, 1(1): 20-24. 